University of Nebraska - Lincoln

DigitalCommons@University of Nebraska - Lincoln

Faculty Publications from the Harold W. Manter Laboratory of Parasitology

2003

Coccidia in the Mammary Glands of Shrews (Order: Insectivora)

Donald W. Duszynski

University of New Mexico, eimeria@unm.edu

William C. Marquardt

Colorado State University, billmarq@comcast.net

Follow this and additional works at: https://digitalcommons.unl.edu/parasitologyfacpubs

Part of the Parasitology Commons

Duszynski, Donald W. and Marquardt, William C., "Coccidia in the Mammary Glands of Shrews (Order: Insectivora)" (2003). Faculty Publications from the Harold W. Manter Laboratory of Parasitology. 140. https://digitalcommons.unl.edu/parasitologyfacpubs/140

This Article is brought to you for free and open access by the Parasitology, Harold W. Manter Laboratory of at DigitalCommons@University of Nebraska - Lincoln. It has been accepted for inclusion in Faculty Publications from the Harold W. Manter Laboratory of Parasitology by an authorized administrator of DigitalCommons@University of Nebraska - Lincoln. 


\title{
Coccidia in the Mammary Glands of Shrews (Order: Insectivora)
}

\author{
Donald W. Duszynski and William C. Marquardt*, Department of Biology, The University of New Mexico, Albuquerque, New Mexico 87131; \\ *Department of Biology, Colorado State University, Fort Collins, Colorado 80523. e-mail: eimeria@unm.edu
}

ABSTRACT: Three of 6 female long-clawed shrews, Sorex unguiculatus Dobson, 1890, collected on the island of Hokkaido, Japan, were found to have unsporulated oocysts and sexual stages (both macro- and microgamonts) in varying stages of development of an unidentified coccidium in both lactating and nonlactating mammary glands. Gamonts developed in the alveoli of the mammary glands, and oocysts were found in the lactiferous ducts and in pools of milk. Mature macrogamonts were $11.9 \times 15.2 \mu \mathrm{m}(10-14 \times 14-20 \mu \mathrm{m})$, whereas completely developed microgamonts with many gametes were $14.8 \times 16.8 \mu \mathrm{m}$ $(10-18 \times 13-20 \mu \mathrm{m})$. Oocysts in tissue sections were $19.5 \times 13.8 \mu \mathrm{m}$ and had a smooth outer wall that was $<1 \mu \mathrm{m}$ thick. Little histopathology was associated with the infections. Infected cells were enlarged and appeared cloudy, and in some areas there was leucocytic infiltration by macrophages, small and large lymphocytes, neutrophils, and eosinophils. No basophil was seen. We also found sections of a nematode, probably a Mammanidula sp., in sections of an active mammary gland in 1 of the shrews not infected with the coccidium.

The Insectivora (shrews and moles) comprises a unique group of eutherian (placental) animals that, as far as is known, lack a cecum as part of their digestive tract. The order comprises 7 families and 428 species (Hutterer, 1993). The majority of insectivore species, $312(73 \%)$, are placed in the Soricidae, and the most cosmopolitan and speciose assemblage within the family, Sorex, has 70 extant species. Only 15 Sorex species (21\%) have ever been examined for coccidia, and from these, 10 species of intestinal coccidia have been described, including 7 Eimeria and 3 Isospora species (Duszynski and Upton, 2000). All 10 species were described originally from oocysts found either in the intestinal contents or in the feces (or in both). In only 1 of these 10 species, E. chagasi Yakimoff and Gousseff, 1935 (which Černá and Daniel [1956] and Černá [1961] called E. komareki), have intestinal endogenous stages been described. Černá (1961) found "gametocytes of various developmental stages ... mostly in mucous parts (= enterocytes?) of the small intestine," with only a few seen in the large intestine.

It was once believed that endogenous stages of coccidia life cycles were confined to epithelial cells of the gastrointestinal tract or its associated ducts and organs, e.g., bile and pancreatic ducts and liver parenchyma. However, there seems to be a growing number of "exceptions," where various endogenous developmental stages have been found in other locations, including cells of the kidney, gallbladder, placenta, uterus, vagina, oviducts, epididymis, seminal vesicles, and lymph nodes (for reviews, see Duszynski and Upton, 2001; Duszynski, 2002). A single report also is known of a coccidium in mammary glands of shrews. Cable and Conaway (1953) reported at a meeting of the American Society of Parasitologists that they had found "all stages" of a coccidium in the mammary glands of $S$. palustris navigator Richardson, 1828 (northern water shrew), collected in Montana as part of a study on the reproductive cycle of this host species. Of 9 animals they examined, 3 postpartum females were infected, and the coccidium stages "were found only in lactating individuals whose mammary tissue showed signs of regression." No publication has appeared after this paper was presented at the meeting.

As part of a long-standing and continuing collaboration between mammalogists and parasitologists at the University of New Mexico (UNM), numerous insectivores and their coccidia parasites have been collected, identified, and archived for the past $25 \mathrm{yr}$ (see summary in Duszynski and Upton, 2000). In most instances, hosts were livetrapped in the field using standard pitfall traps; they were then killed, and fecal contents were collected directly from the intestinal tract. In 1981, 10 of 48 (21\%) S. unguiculatus Dobson, 1890 collected on the Hokkaido Experimental Research Station, Hokkaido, Japan, had coccidia oocysts of E. fumeus and I. palustris in their feces (reported in Hertel and
Duszynski, 1987). With the knowledge of Cable and Conaway's (1953) abstract at the time of collection in 1981, mammary glands of 6 female S. unguiculatus in this collection were fixed in Lillie formal alcohol (see Humason, 1979); these tissues were later embedded in paraffin, sectioned at $\sim 7 \mu \mathrm{m}$, stained in hematoxylin and eosin, and examined under a $100 \times$ oil immersion objective lens of a compound microscope. In retrospect, none of these 6 shrews had oocysts in its feces (Hertel and Duszynski, 1987), but our histological examination, 20 yr later, revealed that 3 of 6 shrews $(50 \%)$ had coccidia at various developmental stages in their mammary glands (Fig. 1), and in some instances, we also saw oocysts in the lactiferous ducts of the mammary gland (Fig. 2).

Two of the 3 infected shrews had inactive mammary glands. Developmental stages were seen in the mammary tissues of 1 of these, but in both animals, oocysts were seen in pools of milk (Fig. 3). In the third infected shrew, the mammary gland was active, as evidenced by alveoli distended with milk, and gamonts of a coccidium were seen in the tissue. Where infections were seen, a lobe of the mammary gland was completely involved (Fig. 4) and all cells of an alveolus appeared to be infected (Fig. 5); examination of the sections of the other lobes of the gland failed to show any infection. All stages of gamogony were seen, from small macrogamonts to nearly completely formed oocysts (Fig. 6). There also was a range of developmental stages of microgamonts from those where the darkly staining nuclei allowed them to be identified as microgamonts (Fig. 7) to those with fully formed microgametes (Fig. 8).

Young microgamonts $(\mathrm{n}=10)$, with few to many scattered (diffuse) nuclei, measured $10.2 \times 12.4 \mu \mathrm{m}(8-13 \times 9-20 \mu \mathrm{m})$. Nearly mature microgamonts $(n=4)$, with many nuclei at or very near the periphery, were $12.0 \times 15.3 \mu \mathrm{m}(10-17 \times 12-21 \mu \mathrm{m})$, and mature microgamonts $(\mathrm{n}=5)$, with many well-formed gametes, were $14.8 \times 16.8 \mu \mathrm{m}(10$ $18 \times 13-20 \mu \mathrm{m})$. Macrogamonts $(\mathrm{n}=10)$ were $11.9 \times 15.2 \mu \mathrm{m}(10$ $14 \times 14-20 \mu \mathrm{m})$, although a few very young forms, $\sim 5 \mu \mathrm{m}$ in diameter, were seen. Wall-forming bodies could be seen in most macrogamonts measured, but they had not yet coalesced at the margins. In a few instances, multiple infections with gamonts were found in 1 cell.

Processing of the tissues for histology caused the oocysts to collapse, but it was clear that they had not yet sporulated. It was possible to obtain an estimate of the size of the oocysts by measuring the space that they occupied in pools of milk in the inactive mammary glands. Oocysts were ellipsoidal and measured $(\mathrm{n}=10) 19.5 \times 13.8 \mu \mathrm{m}$ and were bounded by an outer wall that was smooth and $\sim 1 \mu \mathrm{m}$ thick. Although we recognize the shortcomings of these measurements, they may serve as a guide for future investigations.

Changes in the infected tissues were not striking. In areas such as a whole lobe of the mammary gland, there was a variety of leucocytes in the vicinity of the gamonts. Macrophages, lymphocytes, both small and large, and polymorphonuclear leucocytes were present. Among the polymorphs, eosinophils predominated with a lesser number of neutrophils, but no basophil was recognized. There was no hemorrhage in the vicinity of the gamonts or the infected lobe.

One might reason that infection of the mammary gland would ensure transmission of a parasitic agent to the offspring, as is the case in hookworms of fur seals, Uncinaria lucasi (Olsen and Lyons, 1965), or Ancylostoma caninum of dogs (Kalkoven, 1987). However, despite the oocysts having collapsed during processing, it could be seen clearly that they had not undergone endogenous sporulation. We know that sporulation does take place in the intestinal tracts of the hosts of some coccidia species, especially in snakes and fish, so it is not without precedent. In this cycle, nursing offspring could pass unsporulated oocysts through their intestinal tracts, and the oocysts could then sporulate to be infective for either adults or young. Alternatively, invertebrates in 

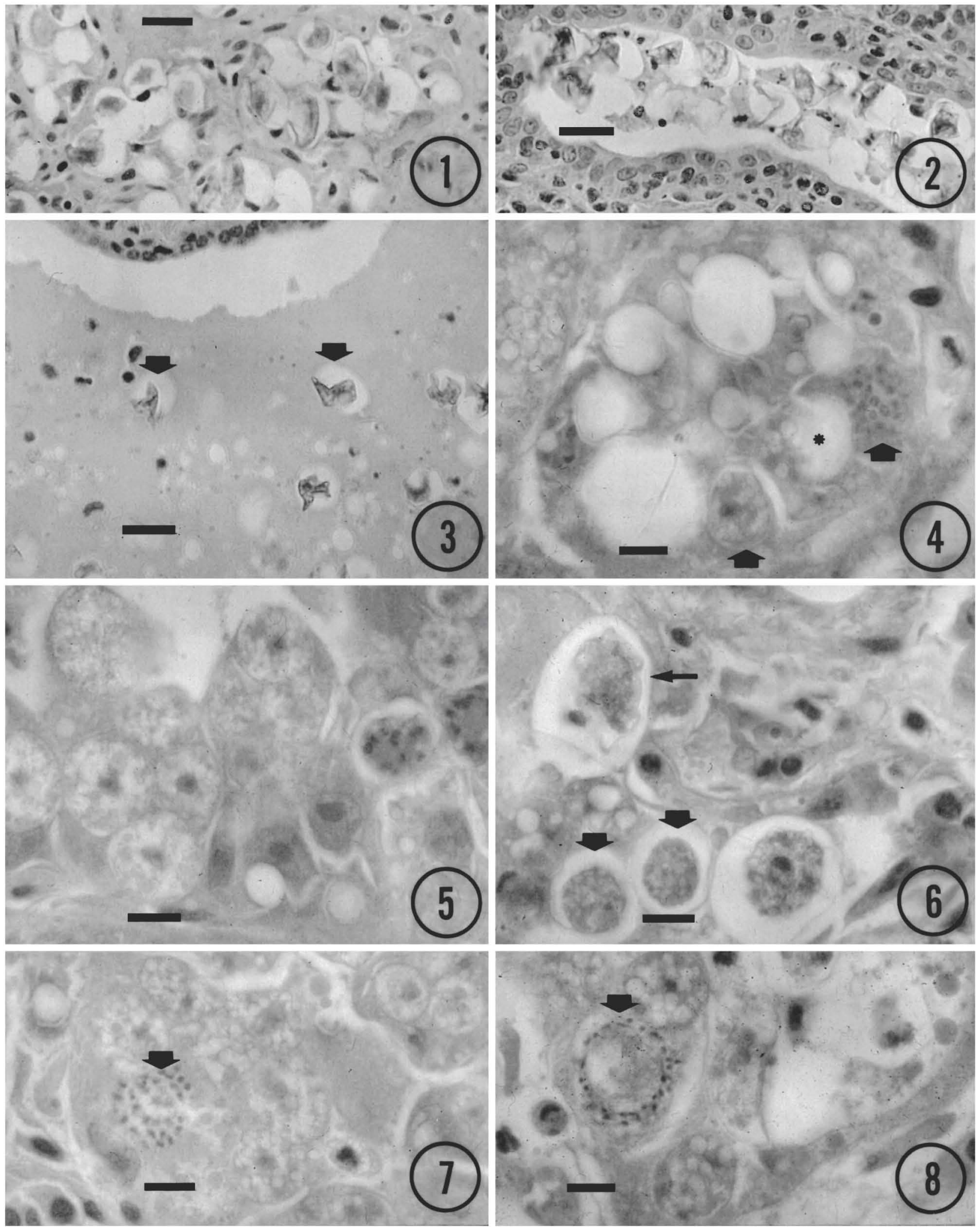

Figures 1-8. Photomicrographs of tissue sections of mammary glands from the long-clawed shrew, Sorex unquiculatus. 1-3. Bar $=20 \mu \mathrm{m}$. 4-8. Bar $=10 \mu \mathrm{m}$. 1. Low power of mammary gland with numerous coccidia developmental stages. 2. Oocysts in the lactiferous ducts of the mammary gland. 3. Oocysts (arrowheads) in pools of milk. 4. Gamonts (arrowheads) and empty oocysts (*) in an active mammary gland; note that the entire lobe of the gland seems to be involved. 5. An alveolus of an active gland; note that all cells appear to be infected even though sections of the other lobes of the gland failed to show any infection. 6. All stages of gamogony were seen, from small macrogamonts (arrowheads) to nearly completely formed oocysts (arrow). 7. Early microgamont with darkly staining nuclei (arrowhead). 8. Mature microgamont with fully formed microgametes (arrowhead). 
the nests of the shrews might ingest sporulated (or unsporulated?) oocysts and serve as intermediate or transport hosts for this parasite.

Merogony was not seen in the mammary tissues, and no developmental stage of coccidia was seen in the small intestines. Cable and Conaway (1953) reported all stages, but we have not been able to find their material and verify their report. Our observation that a whole lobe of mammary gland was infected with gamonts implies that merogony occurred there, but no merogonous stage was seen. In other words, the concentration of gamonts implies that a large number of merozoites either developed in the vicinity or reached there almost simultaneously. Because no meront was seen in the tissues, the former is unlikely. If the latter is the case, how would the merozoites all colonize a single lobe or alveolus? Thus, it is unclear where merogonous stages may develop.

Because oocysts did not sporulate in the mammary tissues, it is impossible to know the genus (genera?) of the parasites seen by Cable and Conaway (1953) in S. palustris navigator from Montana or those that we found in S. unguiculatus from Hokkaido, Japan. This important piece of information awaits a more systematic study and the discovery of sporulated oocysts. The finding of apparently closely related coccidia in members of the same host genus, in North America and in Asia, is intriguing. Further life history studies will reveal whether this is coincidental or whether there exists a unique transmission strategy of coccidia in these mammalian hosts.

Finally, we noted sections of a nematode (or more than 1?) at the margin of the gland, probably in a lactiferous duct, in an active mammary gland of 1 shrew that was not infected with gamogonous stages of the coccidium. In this gland, all the alveoli were well distended with milk and obviously secreting. Given the features of the worm, including the musculature type and especially the spinelike cuticular ridges, the worms are likely trichostrongylids, most likely of a Mammanidula species, known to be parasites of the mammary glands of Old World insectivores and rodents (M. L. Eberhard, pers. comm.).

Thanks are due to C. Schmidley, who prepared the slides of shrew mammary tissue for observation, and M. L. Eberhard, CDC, Atlanta, Georgia, for giving us his best-guess identification of the nematode tissue sections. We thank the following former students of the Department of Biology, UNM, and the Primate Research Institute (PRI), Kyoto University, Japan, for their help in the field collecting and processing shrews: S. B. George, D. W. Moore, D. W. Reduker (deceased), Hidetoshi Ota, Hidetoshi Nagamasu, and Hirokuni Noda. We are indebted to T. Setoguchi and his colleagues of the PRI for logistic and moral support in Japan. A National Science Foundation (NSF) grant (DEB8004685 ) to T. L. Yates (UNM) supported the field trip and collecting expedition to Japan. Finally, this study also was supported, in part, by an NSF-PEET grant (DEB-9521687) to D.W.D.

\section{LITERATURE CITED}

Cable, R. M., and C. H. Conaway. 1953. Coccidiosis of mammary tissue in the water shrew Sorex palustris navigator. Journal of Parasitology 39(supplement): 30 .

ČERNÁ, Ž. 1961. The development of the coccidia Eimeria komareki Černá-Daniel 1956 from Sorex araneus. Vestnik Ceskoslovenske Zoologicke Spolecnosti (=Acta Societatis Zoologicae Bohemoslovenicae) 25: 181-183.

-, AND M. DANIEL. 1956. K Poznáni kokcidií volně zijícíh drobný ssavců. Československá Parasitologie 3: 19-23.

Duszynski, D. W. 2002. Coccidia (Apicomplexa: Eimeriidae) of the mammalian order Chiroptera. Special Publication of the Museum of Southwestern Biology, No. 5. University of First Impressions Printing Services, Albuquerque, New Mexico, $42 \mathrm{p}$.

, AND S. J. UPTON. 2000. Coccidia (Apicomplexa: Eimeriidae) of the mammalian order Insectivora. Special Publication of the Museum of Southwestern Biology, No. 4. University of New Mexico Printing Services, Albuquerque, New Mexico, $67 \mathrm{p}$.

- AND —. 2001. Cyclospora, Eimeria, Isospora, and Cryptosporidium spp. In Parasitic diseases of wild mammals, 2nd ed., W. M. Samuel, M. J. Pybus, and A. A. Kocan (eds.). Iowa State University Press, Ames, Iowa, p. 416-459.

Hertel, L. A., AND D. W. Duszynski. 1987. Coccidian parasites (Apicomplexa: Eimeriidae) from insectivores. III. Seven new species in shrews (Soricidae: Soricinae) from Canada, Japan, and the United States. Journal of Parasitology 73: 172-183.

Humason, G. L. 1979. Animal tissue techniques, 4 th ed. W. H. Freeman and Company, San Francisco, California, $661 \mathrm{p}$.

HutTERER, R. 1993. Order Insectivora. In Mammal species of the world: A taxonomic and geographic reference, 2 nd ed., D. E. Wilson and D. A. M. Reeder (eds.). Smithsonian Institution Press, Washington, D.C., p. 69-139.

Kalkoven, U. P. 1987. Hookworms of dogs and cats. Veterinary clinics of North America. Small animal practice. Parasitic Infections 17: $1341-1354$.

Olsen, O. W., AND E. T. LyONS. 1965. Life cycle of Uncinaria lucasi Stiles, 1901 (Nematoda: Ancylostomatidae) of fur seals, Callorhinus ursinus Linn. on the Pribilof Islands. Journal of Parasitology 51: 689-700. 